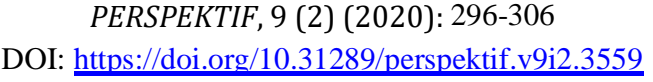

PERSPEKTIF

Available online http://ojs.uma.ac.id/index.php/perspektif

\title{
Faktor Kemenangan Partai Barisan Nasional Malaysia dalam Pemilu Selama 60 Tahun (1957-2018)
}

\section{The Malaysian National Front Party Victory Factor in 60 Years of Election (1957-2018)}

\author{
Dewi Masitoh* \\ Program Studi Magister Ilmu Politik, Fakultas Ilmu Sosial dan Ilmu Pemerintahan, \\ Universitas Diponegoro, Indonesia
}

Diterima: 27 Februari 2020; Disetujui: 08 April 2020; Diterbitkan: 01 Juli 2020

\begin{abstract}
Abstrak
Penelitian ini bertujuan untuk menganalisis beberapa strategi Partai Barisan Nasional dalam menjalankan fungsinya sebagai partai politik di Malaysia. Masalah yang difokuskan pada tulisan ini adalah faktor kemenangan Partai Barisan Nasional Malaysia dalam Pemilu selama 60 tahun. Guna mendekati masalah ini, maka digunakan acuan teori dari Prof. Miriam Budiardjo, yaitu konsep partai politik. Konsep partai politik adalah sebuah sarana dan instrumen untuk masyarakatnya agar dapat berpatisipasi dan berkontribusi dalam mengelola suatu negara. Data-data dikumpulkan melalui data sekunder dan tinjauan pustaka serta dianalisis secara kualitatif. Penelitian ini menyimpulkan bahwa terdapat beberapa faktor yang menyebabkan Barisan Nasional selalu menang dalam pemilu selama 60 tahun yaitu: Pertama, polarisasi dan politik fragmentasi di Malaysia, yaitu berupa kebijakan Bumiputera, income gap dan Chinese Tsunami. Kedua, pengaruh New Economic Policy (NEP) sebagai upaya Affirmative Action serta terdapat kebijakan Mix and Match Policy. Ketiga, Gerrymandering dan deliniasi yaitu berupa sistem pemilihan umum yang dirancang agar Barisan Nasional selalu menang. Keempat, ketidakstabilan dan lemahnya partai oposisi koalisi Pakatan Rakyat.

Kata Kunci: Barisan Nasional, Chinese Tsunami, New Economic Policy, Mix and Match Policy, Gerrymandering.
\end{abstract}

\begin{abstract}
This research aims to analyze the National Front Party's (Barisan Nasional) strategies in carrying out their function as a political party in Malaysia. The problem focused on this paper is the victory factors of the Malaysian National Front Party in the Election for 60 years. To approach this problem, the theoretical framework will be used in this paper from Prof. Miriam Budiardjo's concept, that the concept of a political party. The concept of political party is a tools and instruments for the people to participate and contribute in managing a country. Data from this paper has collected through secondary data and literature review and analyzed qualitatively. This research concluded that there were several factors that led to the National Front always winning in the election for 60 years, they are: First, the polarization and fragmentation politics in Malaysia, it's called by Bumiputera policy, income gap and the Chinese Tsunami. Second, the influence of the New Economic Policy (NEP) as an affirmative action effort and there is a mix and match policy. Third, Gerrymandering and delineation in the form of an electoral system that is designed, so that the National Front always wins. Fourth, the instability and weakness of the Pakatan Rakyat as coalition opposition party.
\end{abstract}

Keywords: The National Front, Chinese Tsunami, New Economic Policy, Mix and Match Policy, Gerrymandering.

How to Cite: Masitoh, D. (2020). Faktor Kemenangan Partai Barisan Nasional Malaysia dalam Pemilu Selama 60 Tahun (1957-2018). PERSPEKTIF, 7 (1) (2020): 296-306.

\footnotetext{
*Corresponding author:

E-mail: dewimasitohlty117@gmail.com
}

ISSN 2085-0328 (Print) ISSN 2541-5913 (online) 


\section{PENDAHULUAN}

Barisan Nasional merupakan sebuah organisasi koalisi berbagai partai-partai politik, lebih tepatnya terdapat 13 partai yang tergabung dalam Koalisi Barisan Nasional. Partai-partai tersebut diantaranya adalah sebagai berikut: Partai United Malays National Organisation (UMNO), Malaysian Chinese Association (MCA), Malaysian Indian Congress (MIC), Malaysian People's Movement Party atau Parti Gerakan Rakyat Malaysia (PGRM), People's Progressive Party (myPPP), Pesaka Bumiputera Bersatu (PBB), Sarawak United People's Party (SUPP), Parti Bersatu Rakyat Sabah (PBRS), Liberal Democratic Party (LDP), Parti Bersatu Sabah (PBS), United Posokmomogun Kadasandusun Murut Organisation (UPKO), Sarawak Progressive Democratic Party (SPDP), Parti Rakyat Sarawak (PRS) (Times, 2018).

Dari ke-13 partai tersebut, terdapat tiga partai terbesar di Malaysia, yaitu: Melayu United Malays National Organisation (UMNO), Malaysian Chinese Association (MCA), Malaysian Indian Congress (MIC). Barisan Nasional Malaysia ini dibentuk untuk mewakilkan masyarakat Malaysia tanpa adanya perbedaan, tidak memandang ras, agama, suku dan etnis (Times, 2018).

Barisan Nasional secara sah pertama kali telah dibentuk sebagai koalisi partai yaitu pada tanggal 1 Juni 1973, dengan sembilan partai yang tergabung (Razak, 2006). Sejak diadakannya pemilu pertama kali di Malaysia yaitu pada tahun 1957, Barisan Nasional selalu memenangkan pemilihan umum, dan hingga 2018 Barisan Nasional tidak kehilangan eksistensinya diantara masyarakat Malaysia. Dengan berbagai kebijakan atau visi dan misi yang dimiliki oleh koalisi Barisan Nasional, Barisan Nasional telah menjadi pilihan utama masyarakat utama dalam setiap pemilihan umum Malaysia (Denny, 2006).

Selama 60 tahun, yaitu dari 31 Agustus 1957 hingga 31 Agustus 2018, Barisan Nasional telah berkuasa sebagai Partai Politik yang sangat berkuasa di Malaysia. Sejak pemilihan umum pada tahun 1974, Barisan Nasional selalu mengalahkan partai oposisi dan selalu mendapatkan lebih dari 100 kursi Parlemen di Malaysia (Ericssen, 2018). Oleh karena itu, dalam penulisan ini akan menjelaskan secara rinci terkait alasan mengapa koalisi Partai Politik Barisan
Nasional sejak tahun 1957 selalu terpilih menjadi pemenang Pemilihan Umum (Pemilu) di Malaysia hingga tahun 2018.

Dalam penulisan ini akan menggunakan konsep partai politik. Dengan menerapkan konsep partai politik ke dalam penulisan ini, maka akan terjawab dari tujuan penulisan ini, yaitu dapat mengetahui dan menganalisis terkait alasan mengapa koalisi politik Barisan Nasional selama 60 tahun, yaitu sejak tahun 1957 hingga 2018 yang selalu menang dalam pemilu.

Konsep partai politik adalah sebuah sarana dan instrumen untuk masyarakatnya agar dapat berpatisipasi dan berkontribusi dalam mengelola suatu negara. Partai politik berfungsi sebagai alat untuk menghubungkan rakyat dengan pemerintah, yaitu sebagai mediator antara keinginan dan kebutuhan masyarakat serta responsivitas pemerintah dalam mendengar tuntutan rakyat (Budiardjo, 2008).

Menurut Carl J. Friedrich mengatakan bahwa partai politik adalah sekelompok manusia yang terorganisir dengan baik dan bertujuan untuk mendapatkan serta mempertahankan kontrolnya atas sebuah kepemimpinan terhadap anggota partai, sehingga mereka semua mendapatkan manfaat dan keuntungan atas kepemimpinannya tersebut (Budiardjo, 2008).

Dengan menggunakan konsep partai politik, maka akan terjawab tujuan penulisan ini, yaitu dapat melihat dari keempat fungsi konsep partai politik terhadap praktik dan fungsi Partai Barisan Nasional di Malaysia. Sehingga, dapat dilihat, seberapa efektif Barisan Nasional telah melakukan fungsinya sebagai partai politik. Partai politik yang telah diterapkan pada negara demokrasi, salah satunya Malaysia mempunyai empat fungsi, yaitu sebagai berikut:

Pertama, sarana komunikasi politik, yaitu terdapat proses penggabungan berbagai kepentingan atau yang biasa disebut dengan agregasi politik (interest aggregation). Setelah digabungkan, beberapa pendapat serta aspirasi tersebut harus diproses lalu dirumuskan ke dalam perumusan kepentingan, yang disebut dengan (interest articulation) (Budiardjo, 2008).

Kedua, sarana sosialisasi politik, yaitu sebuah proses atau upaya yang harus dilakukan oleh seseorang atau kelompok 
dalam menentukan perilaku politik seseorang dengan menyampaikan budaya politik mereka. Dalam menentukan sikap politik seseorang, dapat dilihat dari beberapa aspek, yaitu: suku bangsa, nasionalisme, ideologi, kelas sosial, hak dan kewajiban (Budiardjo, 2008).

Ketiga, sarana rekrutmen politik, yaitu dengan cara menyeleksi atau memilih pemimpin dalam internal partai serta kepemimpinan nasional mereka. Hal ini dapat membuat partai politik mempunyai banyak kader yang baik, sehingga partai dan masyarakat juga dapat dengan mudah untuk menentukan pemimpin mereka sendiri (Budiardjo, 2008).

Keempat, sarana pengatur konflik (conflict management), yaitu partai politik harus menjadi penghubung dan sarana, baik secara organisasional dan psikologis antara pemerintah dan warga negaranya. Dalam hal ini peran partai politik, khususnya kerja sama para elite politik sangat diperlukan untuk mengatasi konflik karena adanya masyarakat heterogen dalam sebuah negara yang akan memicu adanya konflik (Budiardjo, 2008).

Dengan menerapkan konsep partai politik beserta keempat fungsi partai politik di atas, maka dapat terjawab tujuan penulisan ini, yaitu dengan melihat sejauh mana Partai Barisan Nasional telah melakukan beberapa upayanya dalam menjalankan fungsinya sebagai partai politik. Kemudian, dapat mengetahui dan menganalisis terkait alasan mengapa koalisi politik Barisan Nasional selama 60 tahun, yaitu sejak tahun 1957 hingga 2018 yang selalu menang dalam pemilu.

\section{METODE PENELITIAN}

Penulisan ini akan menggunakan metode penelitian kualitatif. Metode penelitian kualitatif adalah metode penelitian yang lebih menekankan pada pengamatan dan pemahaman sebuah fenomena sosial yang kemudian diinterpretasikan dan dijelaskan melalui kata-kata. Objek dari metode penelitian ini adalah manusia, institusi serta interaksi dan perilaku yang ada di dalamnya (McCusker, 2015).

Menurut K. McCusker dan S. Gunaydin dalam bukunya yang berjudul "Research Using Qualitative, Quantitative or Mixed Methods and Choice Based on the Research" mengatakan bahwa metode kualitatif ini sangat cocok digunakan untuk menjawab pertanyaan 'mengapa' atas sebuah fenomena. Metode ini bersifat subjektif dan induktif serta tidak menggunakan mekanisme statistik (McCusker, 2015).

Sehingga, metode kualitatif ini sangat cocok untuk diterapkan ke dalam penulisan ini yang membahas terkait alasan 'mengapa' koalisi politik Barisan Nasional selama 60 tahun selalu menang dalam pemilu.

Metode kualitatif merupakan metode penelitian yang bersifat fleksibel dan dinamis, yang berarti bahwa selalu terbuka terhadap perubahan, baik itu penambahan, pengurangan dan pergantian selama proses penelitian (McCusker, 2015).

Metode kualitatif dapat dilakukan dengan cara mengambil sebuah studi kasus dari permasalahan sosial yang ada. Metode ini juga dilakukan dengan cara mengembangkan nilai serta mengambil kesimpulan berdasarkan pada proses dan data yang telah didapatkan (Direktorat, 2019).

Metode penelitian kualitatif dapat dilakukan dengan dua cara, yaitu: Pertama, eksploratif yaitu dengan mengetahui secara detail tentang objek dan permasalahan yang ada. Kedua, deskriptif yaitu proses kelanjutan setelah eksploratif, di mana proses penelitian ini bertujuan untuk menggambarkan objek atau fenomena yang akan diteliti secara detail. Kemudian, setelah menggunakan kedua metode penelitian ini akan memberikan penjelasan terhadap suatu objek, sehingga akan diambil sebuah kesimpulan sebagai hasil dan intisari dari penelitian ini (Hancock, 2009).

Dengan menggunakan metode kualitatif ini, penulis dapat memberikan beberapa pemaparan dan penjelasan terhadap suatu objek secara rinci. Hasil dari metode kualitatif ini dapat mengarah dan menghasilkan sebuah pengembangan konsep, interpretasi, saran, solusi atau evaluasi dari isu yang telah dibahas oleh penulis. Dan pada bagian akhir, penulis akan mengambil sebuah kesimpulan sebagai hasil dan intisari dari penelitian ini (Hancock, 2009).

Teknik pengambilan data dalam penulisan ini akan menggunakan dengan cara mengambil data sekunder. Data sekunder yaitu sebuah metode yang didapatkan melalui tinjauan pustaka dengan melakukan proses pencarian data-data yang telah diolah dengan 
melakukan pengamatan, perbandingan serta mengambil beberapa referensi atau sumber yang sudah ada, seperti buku, data, jurnal dan artikel melalui internet. Sehingga, dalam penelitian ini akan dibahas secara detail dengan melakukan peninjauan dari beberapa data yang terpercaya melalui internet. Kemudian, data dalam penulisan ini juga bersifat naratif, yaitu kalimat yang menggambarkan kompleksitas dari sebuah permasalahan. (Cochran, 2007).

\section{HASIL DAN PEMBAHASAN \\ Polarisasi Etnis dan Politik Fragmentasi}

Adanya polarisasi etnis serta politik fragmentasi di Malaysia merupakan salah satu alasan Barisan Nasional selalu menjadi pemenang dalam pemilihan umum hingga sekarang. Hal ini akan terbagi menjadi 3 pembahasan, yaitu:

Pertama, kesenjangan pendapatan (income gap). Keadaan polarisasi etnik di Malaysia merupakan dampak dari budaya yang dijadikan kedok dalam perpolitikan oleh partai penguasa, dalam hal ini Barisan Nasional yang menjadi aktor utama atas terjadinya income gap tersebut. Masyarakat etnik melayu mendapat bantuan yang lebih tinggi dibandingkan dengan masyarakat nonmelayu. Kebijakan tersebut sengaja di buat oleh Najib Razak untuk menjaga eksistensi kekuasaan partai politik Malaysia. Di antara proses terjadinya income gap tersebut berupa fenomena, di mana rakyat bumi putra mendapatkan kesempatan yang lebar untuk melakukan bisnis dagang, terutama barang impor dari luar negeri yang masuk kepada ekonomi nasional Malaysia. Sehingga, femomena tersebut akan menjadi bahaya, karena terindikasi dari nilai ketidakadilan oleh partai penguasa yang rasis dengan mengutamakan rakyat Melayu sebagai pelaku pasar dalam perdagangan besar di Malaysia sehingga ketidaksetaraan tersebut dapat memicu adanya konflik (Kanah, 2015).

Jika lebih jauh kita berpikir kritis tentang politik tersebut sebenarnya yang diuntungkan adalah pihak pemerintah yang hanya memikirkan dirinya sendiri. Sedangkan, masayarakat Melayu dijadikan korban dalam perpolitikan yang dampaknya terhitung membahayakan negara tersebut. Karena dengan peningkatan ekonomi yang diawali dengan pendidikan yang didukung penuh oleh pemerintah, khususnya untuk etnis melayu, diharapkan sumber daya masyarakat melayu jauh lebih unggul dari etnis yang lain. Sehingga, pada akhinya perekonomian juga dapat dikuasai oleh etnis melayu di Malaysia. Majelis tinggi UMNO pernah mengatakan bahwa sifat berdikari menjadi solusi dari permasalahan ekonomi yang dilatarbelakangi oleh rasis antar etnik Melayu, China dan India tersebut (Gaol, 2010).

Kedua, kebijakan Bumiputera yaitu, "Anak Dari Tanah Melayu" harus disekolahkan agar mereka menjadi orang-orang yang terdidik. Sebagaimana yang kita ketahui bahwa di Negara Malaysia merupakan negara kesatuan yang terdiri dari 3 etnis besar yaitu Melayu, China dan India. Pada tahun 2018 hingga 2019 jumlah penduduk asli Malaysia mengalami peningkatan, sedangkan penduduk non-Malaysia semakin berkurang. Pada tahun 2018, jumlah penduduk asli Malaysia sebanyak 29.1 juta orang dan meningkat pada tahun 2019 sebanyak 29.4 Juta orang. Sedangkan, jumlah penduduk non-Malaysia mengalami penurunan, di mana pada tahun 2018, sebanyak 3.3 Juta orang dan menurun pada tahun 2019 menjadi 3.2 Juta orang. Kemudian, terdapat beberapa persentase berdasarkan etnis di Malaysia, di mana etnis Melayu asli atau Bumiputera lebih dominan daripada beberapa etnis lainnya, seperti China dan India. Hal ini dapat dilihat pada gambar di bawah ini (Department of Statistics Malaysia, 2019):

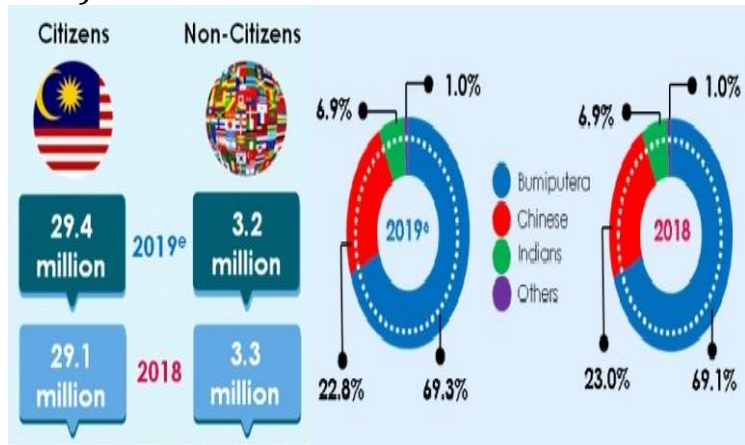

Gambar 1: Jumlah Populasi Penduduk Malaysia Berdasarkan Etnis (2018-2019)

Adanya ketiga etnis yang dominan di Malaysia, yaitu Bumiputera China dan India seharusnya membuat pemerintah lebih berhati-hati dalam mengambil kebijakan. Sehingga, hal ini menyebabkan etnis Melayu memiliki persaingan yang cukup besar dalam hal ekonomi maupun pendidikan. Oleh karena 
itu, hal ini membuat Mahathir sebagai Perdana Menteri Malaysia pada saat itu mengeluarkan kebijakan untuk lebih mensejahterakan masyarakat Melayu dengan cara memberikan pendidikan yang bagus dan tempat tinggal yang layak. Mahathir merasa bahwa Negara Malaysia memiliki etnis pribumi yaitu etnis Melayu, sehingga seharusnya yang mendominasi di sana adalah etnis Melayu. Salah satu kebijakannya adalah adanya beberapa sekolah swasta berdasarkan etnis, harus terdapat kebijakan bahwa di sekolah harus ada pelajaran mengenai Bahasa Melayu, apabila terdapat bantuan subsidi dari Malaysia itu sendiri (DW, 2013).

Ketiga, adanya 'Chinese Tsunami', kebijakan saat ini adalah adanya kebijakan 'New Economic Policy' yang dicetuskan oleh Mahathir Mohammad menimbulkan permasalahan-permasalahan yang melibatkan etnis tersebut. Pada tahun 2010, yaitu pada pidatonya di depan UMNO akan membuat doktrin '1 Malaysia'. Hal ini tentu saja menjadi perdebatan karena pemerintahan Malaysia lebih mementingkan mempersatukan Malaysia tanpa melihat pertimbangan-pertimbangan lain yaitu keanekaragaman etnis. Sehingga, hal ini dapat menimbulkan paradigma mengenai ras. Paradigma mengenai ras yang dibentuk oleh Najib Razak membuat kepentingankepentingan etnis minoritas di Malaysia terancam. Pada tahun 2013, pemerintah Najib Razak mengalami kekalahan di daerah perkotaan semenanjung Malaysia, di mana penduduk di daerah tersebut sebagian besar adalah Chinese justru mendukung tim Oposisi yaitu Pakatan rakyat (Milner, 2014).

'Chinese Tsunami' ini hampir dapat menggulingkan Barisan Nasional karena etnis china lebih memihak dan mendukung ke Partai Oposisi, yaitu Pakatan Rakyat. Pakatan Rakyat hampir memenangkan lebih banyak suara dibandingkan Barisan Nasional, namun dikarenakan adanya distorsi dalam pendistribusian suara terhadap Partai Oposisi, maka Pakatan Rakyat hanya mendapatkan 89 kursi, sementara Barisan Nasional 133 kursi. Kemudian, Najib Razak menyebutkan bahwa hampir kekalahannya tersebut sebagai akibat adanya Chinese Tsunami (Palatino, 2013). Tindakan yang telah dilakukan oleh etnis China tersebut didasari pada kebijakan Barisan Nasional yang selama memimpin Malaysia tidak berpihak pada etnis China tersebut. Hal tersebut dikarenakan Barisan Nasional memberikan hak-hak yang lebih istimewa kepada etnis Melayu sedangkan etnis lainnya yaitu China dan India hanya berada di kelas kedua. Sehingga, hal ini membuat etnis China merasa marah dan berbelok arah mendukung tim Oposisi yaitu Pakatan Rakyat (Webmaster, 2013).

\section{Pengaruh 'New Economic Policy' (NEP) serta 'Mix and Match Policy'}

Pertama, 'New Economic Policy' (NEP) ini dimulai pada tahun 1970-an yang dimulai pada saat Perdana Menteri Tun Abdul Razak. New Economic policy (NEP) adalah kebijakan program ekonomi yang lebih mengutamakan Bumiputera atau etnis Melayu untuk terlibat dalam perekonomian negara, baik sektor swasta maupun kepemilikan properti komersial. Kebijakan 'New Economic policy' (NEP) disebut sebagai 'Affirmative Action' yaitu tindakan yang berbasis pada perlindungan (patronage). Hal ini diimplementasikan dengan adanya hak istimewa terhadap Bangsa Melayu (Bumiputera), sehingga akan menciptakan pertumbuhan ekonomi yang efektif antar etnis Melayu saja. Tetapi, di salah satu sisi membuat mental Bangsa Melayu (Bumiputera) yang tidak dapat mandiri dan selalu dibantu (crutch mentality). Secara otomatis, Malaysia telah melakukan upaya dalam bertahan hidup 'survive' dengan cara mereka sendiri untuk memenuhi kepentingan serta mendapatkan keuntungan yang maksimal (Church, 2009).

Kebijakan NEP ini lebih mengutamakan etnis Malaysia karena telah memiliki sejarah sebelumnya, di mana pada saat Malaysia diterobos oleh tentara koloni dan para pendatang. Masyarakat Melayu tidak dapat melawan mereka, akan tetapi mereka terus mengancam. Mereka mengancam dengan merubah kedudukan sosial atau hak istimewa Melayu di Malaysia (Julian, 2007). Ketika Malaysia masih dijajah oleh Inggris, Malaysia juga sudah mendapatkan hak istimewa dari Inggris, yaitu berupa kuota untuk beasiswa publik dan pekerjaan pegawai negeri. Setelah masa penjajahan, Inggris meninggalkan warisan terhadap masyarakat Malaysia, yaitu pembagian sistem ekonomi dan lokasi geografis yang dibagi berdasarkan ras. Sehingga, dari pembagian tersebut, mayoritas orang-orang Melayu mendapatkan pekerjaan 
dan pendapatan dari sektor pertanian tradisional. Sektor pertanian tradisional ini merupakan sektor yang pendapatannya paling rendah di antara sektor lainnya, sehingga mayoritas orang Melayu miskin (Julian, 2007).

Dan sebaliknya, setelah masa penjajahan dan hasil dari warisan koloni, etnis China yang ada di Malaysia justru terkonsentrasi pada sektor manufaktur, pertambangan dan konstruksi. Dari beberapa sektor inilah, etnis China mendapatkan penghasilan yang tinggi, sehingga mayoritas dari mereka adalah orang kaya. Hal ini terbukti bahwa dari seluruh jumlah rumah tangga yang ada di Malaysia, etnis Malaysia yang mayoritas mengalami kemiskinan, yaitu sebanyak $74 \%$. Sedangkan, etnis China hanya $17 \%$ dan etnis India hanya $8 \%$ Dari peristiwa itulah, Malaysia menciptakan kebijakan New Economic Policy (NEP) pada Juni 1970 untuk menyelesaikan masalah kemiskinan dan ketimpangan ekonomi oleh etnis Melayu (Zubedy, 2012).

Target yang ingin dicapai oleh kebijakan 'New Economic Policy' ini ingin mengurangi tingkat kemiskinan Malaysia menjadi $16.7 \%$. Selain itu, kebijakan ini akan meningkatkan penghasilan masyarakat Bumiputera dari 2.4 $\%$ menjadi $30 \%$. Penghasilan masyarakat China, India dan lainnya meningkat dari 34.3 $\%$ menjadi $40 \%$, dan masyarakat asing lainnya berkurang dari $63.3 \%$ menjadi $30 \%$ saja. Rasio perbandingan antara Bumiputera, masyarakat China dan India serta masyarakat asing memiliki perbandingan 30:40:30 (Zubedy, 2012).

Untuk mencapai target yang berpihak kepada Bumiputera, pemerintah harus melakukan peningkatan sebesar $30 \%$ pertahunnya. Kebijakan ini juga yang dapat membantu Bumiputera untuk bekerja dalam beberapa sektor penting di Malaysia. Secara tidak langsung, New Economic Policy (NEP) merupakan upaya yang telah dirancang agar Melayu mempunyai pendapatan yang lebih tinggi daripada bangsa atau etnis lainnya (Zubedy, 2012).

Kedua, adanya 'Mix and Match Policy', salah satunya yaitu membangun industrialiasi di Malaysia. Pada masa kolonial awalnya pemerintah mengembangkan agrikultur dan eksploitasi bahan tambang yang mengharuskan penebangan hutan besarbesaran. Kebijakan industrialisasi yang telah dibuat oleh kolonial tersebut, kemudian mengundang banyaknya investor asing masuk ke Malaysia, mengingat populasi pada saat kolonialisasi masyarakat Malaysia masih sedikit. Dengan sedikitnya populasi tersebut kemudian didatangkan imigran dari China untuk bekerja di Malaysia pada saat kolonialisasi. Kemudian, industrialisasi berkelanjutan, yaitu pada pasca penyerahan kedaulatan dari pemerintah kolonial Inggris ke Federasi Malaya, pemerintahan dikendalikan oleh Koalisi Barisan Nasional yang merupakan koalisi multipartai dan multietnis serta dipimpin oleh UMNO (Budiwirano, 2008).

Pada tahun 1963 Federal Industrial Development Authority (FIDA) dibangun atas dasar tujuan dari World Bank untuk merekomendasikan pemerintahan Malaysia dalam mengatur dan membuat kebijakan investasi industri di Malaysia. Namun pada tahun 1979 Federal Industrial Development Authority (FIDA) berubah menjadi Malaysian Industrial development Authority (MIDA) untuk merefleksikan bahwa hal ini merupakan milik Malaysia. Puncak dari industrialisasi Malaysia dimulai dengan ditandai adanya The First Industrial Master Plan (1986-1995). Pada tahapan ini pemerintah merencanakan bagaimana upaya ke depannya untuk sektor manufaktur pada periode 1986 hingga 1995 (Malaysian Investment Development Authority, 2012).

Dengan adanya kebijakan mengenai New Economic Policy (NEP), yaitu bagaimana untuk lebih membuat kehidupan warga pribumi lebih baik dari pada etnis lainnya. Mantan perdana Menteri Mahathir Mohammad merasa bahwa seharusnya Negara Malaysia harus dikuasai oleh etnis pribumi sendiri dan jangan sampai dikuasai oleh etnis asing lainnya. (Surin, 2015). Hal ini bertujuan untuk mengurangi dan mengentaskan kemiskinan yang terjadi di Malaysia serta meningkatkan pendapatan dan kesempatan kerja untuk semua warga Malaysia (Gaol, 2010).

\section{Gerrymandering dan 'Deliniasi'}

Kemenangan koalisi Barisan Nasional Malaysia telah melakukan beberapa upaya, salah satunya adalah adanya praktek 'gerrymandering'.

Pertama, Gerrymandering adalah sebuah manipulasi hasil pemilihan umum (pemilu), yaitu dengan cara memanipulasi pembagian batas-batas wilayah pemilihan umum yang 
akan menghasilkan kemenangan bagi salah satu kandidat utama. Gerrymandering ini dapat dilakukan dan dijelaskan, seperti gambar dibawah ini (Ingraham, 2015):

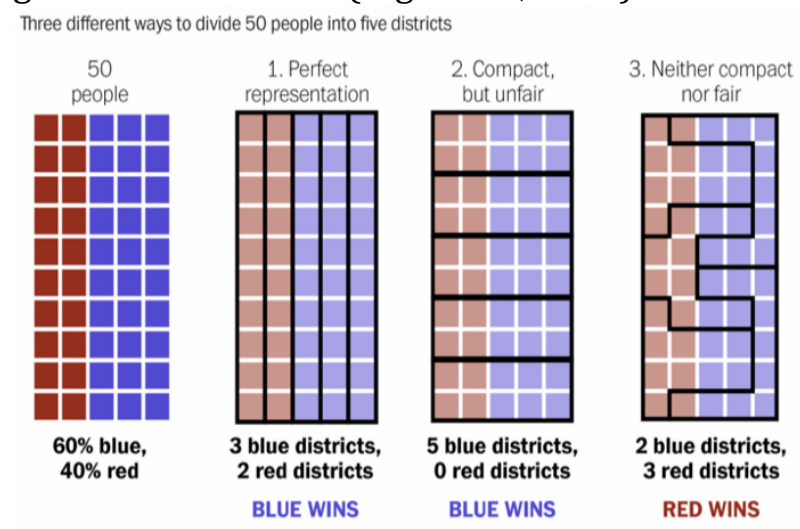

Gambar 2: Penjelasan 'Gerrymandering'

Pelaksanaan gerrymandering tersebut muncul pada tahun 2013, yaitu ketika Malaysia melaksanakan pemilihan umum (pemilu) dan menghasilkan kemenangan bagi koalisi Barisan Nasional yaitu sebanyak $47 \%$ suara dan mendapatkan $60 \%$ jatah kursi di parlemen, atau sekitar 222 kursi diparlemen. Dan untuk lawan politiknya yaitu Koalisi oposisi, Pakatan Rakyat memenangkan $51 \%$ suara dari rakyat, namun hanya mendapatkan $40 \%$ kursi di parlemen, yaitu lebih sedikit dibandingkan dengan Barisan Nasional. Padahal seharusnya pakatan Rakyat lah yang mendapatkan kursi lebih banyak di parlemen dibandingkan dengan Barisan Nasional (Economist, 2014).

Hal ini dapat dibuktikan pada tabel berikut, yaitu hasil dari popular votes pemilu Malaysia pada tahun 2013 dari koalisi Barisan Nasional dan Pakatan Rakyat (Rajaratnam, 2013):

Tabel 1:Popular Votes Hasil Pemilu Malaysia (2013)

\begin{tabular}{|l|l|l|}
\hline Coalition & \multicolumn{1}{l|}{ Total Vote } & $\%$ \\
\hline \multicolumn{3}{|l|}{ Peninsular Malaysia } \\
\hline Pakatan Rakyat & $5,035,611$ & 53.29 \\
\hline Barisan Nasional & $4,322,139$ & 45.74 \\
\hline Others & 89,986 & 0.95 \\
\hline \multicolumn{3}{|l|}{ Nationwide } \\
\hline Pakatan Rakyat & $5,623,984$ & 50.87 \\
\hline Barisan Nasional & $5,237,699$ & 47.38 \\
\hline Others & 192,894 & 1.74 \\
\hline
\end{tabular}

Kedua, 'deliniasi', yaitu dengan cara pemilihan ulang, maksud dari deliniasi ini yaitu Barisan Nasional mencari banyak dukungan berasal dari etnis mayoritas
Malaysia yaitu etnis Melayu. Sehingga, sistem pemilu yang di terapkan di Malaysia memang sengaja dirancang untuk memberikan kemenangan bagi Barisan Nasional (Puyok, 2013).

Hal ini terbukti dengan adanya Barisan Nasional telah mendapat dukungan yang sangat kuat dari masyarakat Melayu yang menjadi mayoritas, yaitu sekitar $60 \%$ dari populasi Malaysia. Oleh karena itu, dengan adanya kebijakan-kebijakan yang sangat menguntungkan dan istimewa bagi masyarakat Melayu yang telah menjamin sektor ekonomi, pendidikan, pekerjaan, seperti program Bumiputera maka Barisan Nasional akan selalu menang. Hal ini dapat dibuktikan dengan pemilu yang telah dilakukan Malaysia sejak dahulu, salah satunya yaitu dari tahun 1999 hingga 2008. Barisan Nasional selalu menang dari hasil popolar vote dan distribusi kursi di Parlemen, seperti grafik di bawah ini (Nehru, 2013):

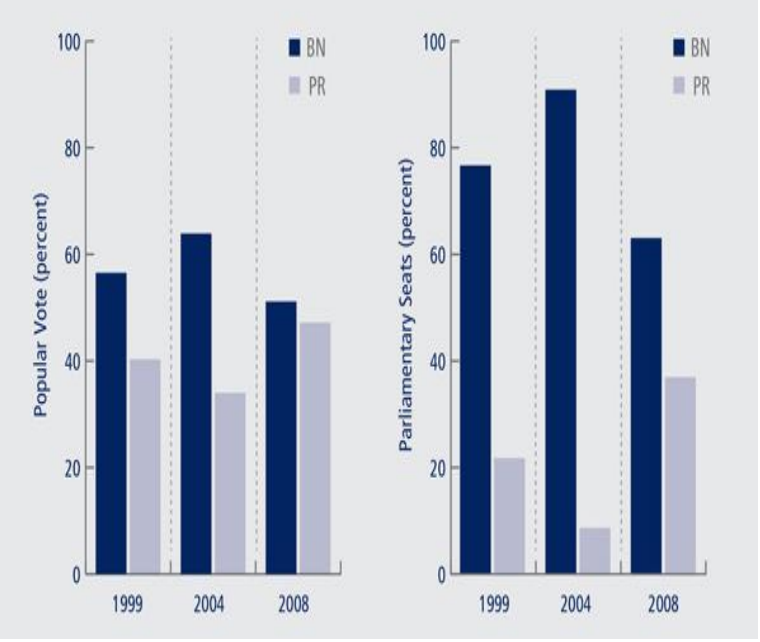

Gambar 3: Populer Votes and Parliamentary Seats Distribution (1999-2008)

\section{Ketidakstabilan dan Lemahnya Partai Oposisi Koalisi Pakatan Rakyat (PR)}

Koalisi Pakatan Rakyat dapat disebut sebagai satu-satunya ancaman bagi Barisan Nasional dalam perebutan suara pada saat pemilu. Namun sayangnya, kondisi internal dari Pakatan Rakyat sendiri dapat dibilang cukup rapuh untuk mempertahankan sebuah koalisi yang kokoh. Hal ini tercermin dari bagaimana Pakatan Rakyat yang dinilai belum mampu menangani perselisihan antar partai dan antar anggotanya (Noh, 2014).

Belum lagi adanya cerminan ketidakjelasan kebijakan dalam internal koalisi 
yang saling bertolak belakang. Salah satu contoh kasus yang dibahas oleh A. Noh ialah Ketua Dewan Ulama Partai Islam PAS, Harun Taib, yang mengeluarkan statement bahwa PAS harus menerapkan hukum syariah tanpa takut terhadap aliansi-aliansi lain dari Pakatan Rakyat (Noh, 2014).

Kemudian, adanya perbandingan jumlah distribusi kursi di parlemen yang sangat berbeda jauh antara Barisan Nasional dan Pakatan Rakyat. Hal ini terbukti pada tahun 2013, Barisan Nasional memiliki jumlah kursi lebih banyak dibandingkan Pakatan Rakyat. Terdapat 137 kursi dari seluruh koalisi Barisan Nasional, yaitu sebanyak 13 partai. Di mana, United Malays National Organization (UMNO) mendapatkan kursi yang paling banyak, yaitu 78 kursi, dan masih ada beberapa partai koalisi lainnya juga. Lebih jelasnya dapat dilihat pada grafik distribusi jumlah kursi parlemen Barisan Nasional di bawah ini (Nehru, 2013):

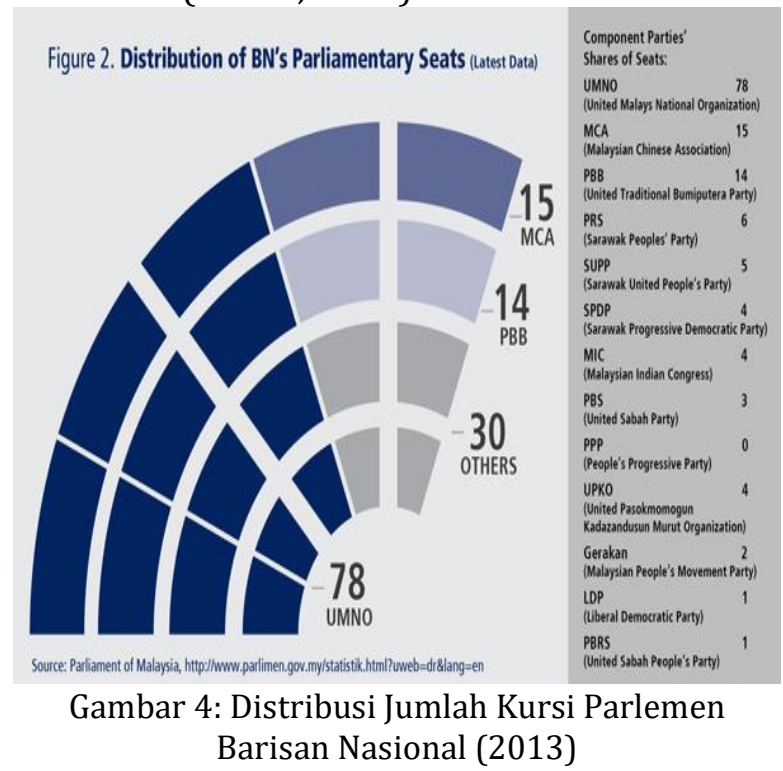

Pakatan Rakyat hanya mendapatkan 76 kursi dari seluruh koalisi Pakatan Rakyat, yaitu terdapat 4 koalisi partai. Yaitu terdiri dari: 29 kursi Democaratic Action Party (DAP), 23 kursi People's Justice Party (PKR), 23 kursi PanMalaysian Islamic Party (PAS) serta 1 kursi Socialist Party of Malaysia (PSM). Hal ini dapat dilihat pada grafik sebagai berikut (Nehru, 2013):

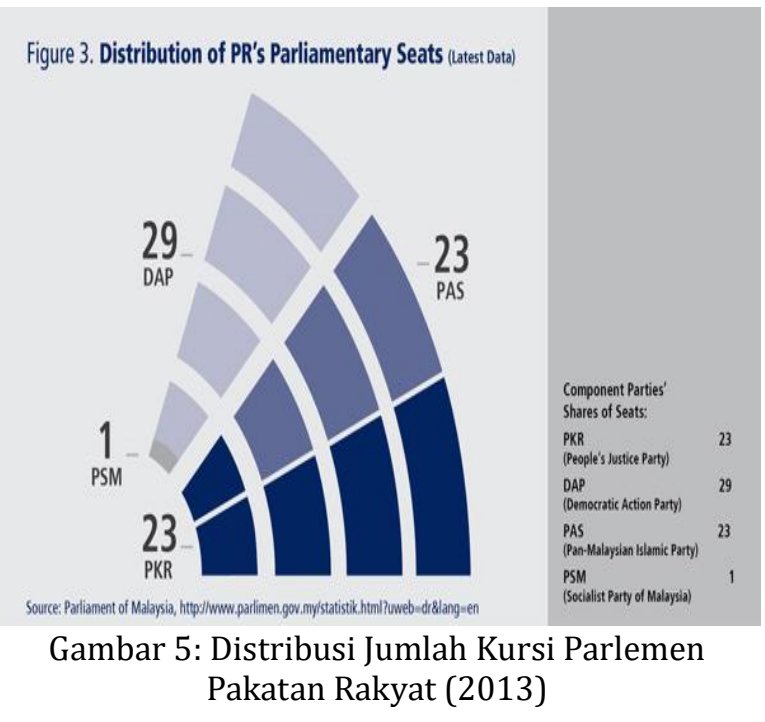

Analisis Konsep Partai Politik terhadap Kemenangan Barisan Nasional Malaysia Selama 60 Tahun (1957-2018)

Apabila melihat beberapa upaya yang telah dilakukan oleh Pemerintah Malaysia, khususnya Partai Barisan Nasional ini, maka dapat dilihat bahwa partai politik sebagai sebuah sarana dan instrumen untuk masyarakatnya agar dapat berpatisipasi dan berkontribusi dalam mengelola suatu negara (Budiardjo, 2008). Barisan Nasional telah melakukan fungsinya sebagai partai politik, yaitu:

Pertama, sebagai sarana komunikasi politik, telah jelas bahwa Barisan Nasional telah melakukan beberapa kebijakan, seperti: Bumiputera, New Economic Policy (NEP), Mix and Match Policy untuk mensejahterakan masyarakat Malaysia. Sehingga, Barisan Nasional di sini telah mencerminkan fungsinya dalam melakukan agregasi politik (interest aggregation) dan kemudian telah diterapkan ke dalam perumusan kepentingan (interest articulation) (Budiardjo, 2008). Tetapi, di salah satu sisi Barisan Nasional masih belum berhasil dalam mensejahterakan beberapa etnis lainnya, seperti China dan India yang masih mengalami beberapa diskriminasi.

Kedua, sebagai sarana sosialisasi politik, di mana Barisan Nasional telah berhasil dalam menentukan politik seseorang dengan menyampaikan budaya politik mereka terhadap masyarakat. Hal ini terbukti bahwa adanya upaya untuk mempertahankan suku bangsa mereka yang merupakan suatu hubungan kelompok manusia, di mana terjalin karena identitas serta kesadaran tentang 
kesatuan kebudayaan (Koentjaraningrat, 2009). Oleh karena itu, suku bangsa ini dapat menciptakan rasa nasionalisme dalam jiwa Bangsa Melayu (Bumiputera). Rasa nasionalisme ini dapat menciptakan sebuah bangsa yang dapat dibangun dari dalam pikiran mereka melalui 'Sosialisasi Politik'.

Secara tidak langsung, 'Sosialisasi Politik' serta 'Parsialitas Nasional' yang dilakukan oleh Barisan Nasional telah berhasil untuk mendapatkan serta menjaga posisi mereka agar selalu bertahan dan berkuasa dalam Politik Pemerintahan di Malaysia. Sosialisasi politik merupakan proses yang didalamnya terdapat beberapa individu dan mempunyai nilai serta keyakinan politik. Kemudian, mereka menyebarkan nilai serta keyakinan politik tersebut dari satu generasi terhadap generasi lainnya. Hal ini bisa terjadi pada aktor primer sosialisasi politik, seperti keluarga dan sekolah, sedangkan aktor sekunder, seperti agama, ras, gender dan media massa (Heywood, 2013). Jadi, secara tidak langsung, Bangsa merupakan 'Komunitas Politik Alami' yang akan menimbulkan 'Parsialitas Nasional'. 'Parsialitas Nasional' yaitu kecenderungan dalam memprioritaskan kepentingan serta kebutuhan dari masyarakatnya terlebih dahulu dibandingkan masyarakat lainnya (Heywood, 2013).

Ketiga, sebagai sarana rekrutmen politik, telah jelas bahwa Barisan Nasional telah mempertahankan kepemimpinanya selama 60 tahun, yaitu dari tahun 1957 hingga 2018. Hal ini tentunya dilakukan dengan cara menyeleksi atau memilih pemimpin dalam internal partai serta kepemimpinan nasional mereka. Sehingga, Barisan Nasional dapat membuat partai politik mempunyai banyak kader yang baik dan dapat mempertahankan kekuasaan mereka. Kemudian, partai dan masyarakat juga dapat dengan mudah untuk menentukan pemimpin mereka sendiri (Budiardjo, 2008).

Keempat, sebagai sarana pengatur konflik (conflict management), di mana Barisan Nasional telah melakukan beberapa upayanya dalam mengatasi konflik antar etnis Malaysia dalam berbagai sektor, seperti ekonomi, politik dan pendidikan. Tetapi, di salah satu sisi Barisan Nasional masih belum bisa mengatasi konflik berbagai etnis lainnya, seperti China, India dan etnis asing lainnya yang tinggal di Malaysia. Hal ini karena masih terdapat beberapa etnis China dan India yang masih mengalami diskriminasi, seperti: kebijakan New Economic Policy (NEP) sebagai upaya 'affirmative action', yaitu tindakan yang berbasis pada perlindungan (patronage) etnis Melayu saja. Kemudian, masih adanya income gap, upaya gerrymandering serta 'deliniasi', yaitu pemilihan ulang, di mana Barisan Nasional mencari banyak dukungan berasal dari etnis mayoritas Malaysia yaitu etnis Melayu (Puyok, 2013). Sehingga, dalam fungsi partai politik sebagai sarana pengatur konflik ini, Barisan Nasional masih belum bisa menjadi sarana dan penghubung yang baik antara pemerintah dan masyarakatnya.

Sehingga, dari keempat fungsi politik di atas, Barisan Nasional telah melakukan beberapa upaya dan kebijakannya dalam mengimplementasikan fungsi partai politik dengan sebaik mungkin. Tetapi, upaya tersebut, terdapat beberapa yang berhasil dan yang belum berhasil. Fungsi politik yang benar-benar berhasil dilakukan oleh Barisan Nasional adalah sebagai sarana sosialisasi politik, rekrutmen politik. Tetapi, sebagai sarana komunikasi politik dan pengatur konflik (management conflict) masih belum bisa dikatakan berhasil karena masih terdapat beberapa etnis lainnya, seperti China dan India yang masih belum bisa mengaspirasikan pendapatnya dan memenuhi kepentingannya sebagai warga Malaysia.

\section{SIMPULAN}

Barisan Nasional merupakan sebuah organisasi koalisi berbagai partai-partai politik, lebih tepatnya terdapat 13 partai yang tergabung dalam Koalisi Barisan Nasional. Sejak diadakannya pemilu pertama kali di Malaysia yaitu pada tahun 1957 hingga 2018, Barisan Nasional selalu memenangkan pemilihan umum (Denny, 2006). Terdapat beberapa alasan dan faktor dari kemenangan Barisan Nasional, yaitu sebagai berikut: Pertama, polarisasi dan politik fragmentasi di Malaysia, yaitu terdapat kesenjangan pendapatan (income gap), kebijakan Bumiputera (Anak Dari Tanah Melayu) yang harus disekolahkan agar mereka menjadi orang-orang yang terdidik serta 'chinese tsunami' yang hampir dapat menggulingkan Barisan Nasional karena etnis china lebih memihak dan mendukung ke Partai Oposisi, yaitu Pakatan Rakyat. Kedua, pengaruh New 
Economic Policy (NEP) yaitu kebijakan program ekonomi yang lebih mengutamakan Bumiputera atau etnis Melayu untuk terlibat dalam perekonomian negara, baik sektor swasta maupun kepemilikan properti komersial. Kebijakan NEP ini sebagai 'Affirmative Action' yaitu tindakan yang berbasis pada perlindungan (patronage) antar etnis Malaysia saja Kemudian, adanya kebijakan Mix and Match Policy, yaitu dengan cara membangun industrialiasi di Malaysia. Ketiga, gerrymandering yaitu memanipulasi pembagian batas-batas wilayah pemilihan umum yang akan menghasilkan kemenangan bagi salah satu kandidat utama. Selain itu, adanya upaya 'deliniasi', yaitu pemilihan ulang, di mana Barisan Nasional mencari banyak dukungan berasal dari etnis mayoritas Malaysia yaitu etnis Melayu (Puyok, 2013). Keempat, ketidakstabilan dan lemahnya partai oposisi koalisi Pakatan Rakyat. Kondisi internal dari Pakatan Rakyat sendiri dapat dibilang cukup rapuh untuk mempertahankan sebuah koalisi yang kokoh. Hal ini tercermin dari bagaimana Pakatan Rakyat yang dinilai belum mampu menangani perselisihan antar partai dan antar anggotanya (Noh, 2014). Kemudian, adanya ketidakjelasan kebijakan dalam internal koalisi yang saling bertolakbelakang. Serta perbandingan jumlah distribusi kursi di parlemen yang sangat berbeda jauh antara Barisan Nasional dan Pakatan Rakyat (Nehru, 2013).

\section{DAFTAR PUSTAKA}

Budiardjo, M. (2008). Dasar-Dasar Ilmu Politik (Edisi Revisi). Jakarta: PT. Gramedia Pustaka Utama.

Budiwirano. (2008). Pertarungan Negara vs Pasar. Yogyakarta: Media Press.

Church, P. (2009). Malaysia: A Short History of Southeast Asia. (5th Edition). Singapura: John Wiley \& Sons (Asia) Pte Ltd.

Cochran, M. \& Patton, M.Q. (2007). A Guide To Using Qualitative Research Methodology. Medecins Sans Frontieres Journal. 4-9.

Denny, J. (2006). Melewati Perubahan: Sebuah Catatan Atas Transisi Demokrasi Indonesia. Yogyakarta: PT. LKis Pelangi Aksara.

Department of Statistics Malaysia, Official Portal. (2019). The Source of Malaysia's Official Statistics, Current Population Estimates, Malaysia, 2018-2019. Malaysia, 15 Juli 2019.

Direktorat, J. K. (2019). Memahami Metode Penelitian Kualitatif. Direktorat Jenderal
Kekayaan Negara Kementerian Keuangan. Artikel DJKN. 06 Maret.

DW. (2013). PM Najib: Malaysia Butuh Pemerintah Kuat. DW. Malaysia, 27 Maret.

Economist, T. (2014). What's Malay for Gerrymandering?. The Economist: Malaysian Politics. Kuala Lumpur, 9 Agustus.

Ericssen. (2018). Mahathir Menang, 60 Tahun Hegemoni Koalisi Partai Penguasa Malaysia Berakhir. Kompas Internasional. Kuala Lumpur, 10 Mei.

Gaol, H. L. (2010). Kebijakan Bumiputera Malaysia 'Mahal'. BBC. Malaysia, 30 Maret.

Gaol, H. L. (2010). Siapa yang Untung Dari Politik Bumiputra? BBC. Malaysia, 3 April.

Hancock, B. Ockleford, E. Windrige, K. (2009). An Introduction to Qualitative Research. National Institute for Health Research (NHS). 6-7.

Heywood, A. (2013). Politik (Edisi Keempat). Yogyakarta: Pustaka Pelajar.

Ingraham, C. (2015). This is the Best Explanation of Gerrymandering You Will Ever See. The Washington Post. Malaysia, 1 Maret.

Julian, C.H.L. (2007). Barisan Nasional - Political Dominance and the General Elections of 2004 in Malaysia. Journal of Current Southeast Asian Affairs, GIGA German Institute of Global and Area Studies, SSOAR. 26 (2): 55-56.

Kanah, G. (2015). Inequality in Malaysia, is it too bad?. Malaysia Kini News. Malaysia, 25 September.

Koentjaraningrat. (2009). Pengantar Ilmu Antropologi (Edisi Revisi). Jakarta: PT. Rineka Cipta.

Malaysian Investment Development Authority, M. (2012). Malaysian Investment Development Authority (MIDA). Malaysia: Corporate Milestones.

McCusker, S. G. (2015). Research Using Qualitative, Quantitative or Mixed Methods and Choice Based on the Research. New York: New York Medical College.

Milner, A. Embong, A.R. \& Yean, T.S. (2014). Transforming Malaysia: Dominant and Competing Paradigms. Institute of Southeast Asian Studies Journal. 29 (2): 5.

Nehru, V. (2013). Understanding Malaysia's Pivotal General Election. Carnegie Endowment for International Peace. Malaysia, 10 April.

Noh, A. (2014). Malaysia's Dilemma: Economic Reforms But Politics Stay The Same. Malaysia: Southeast Asian Affairs.

Palatino, M. (2013). Malaysia's Election "Tsunami": Following the recent elections, PM Najib Razak is facing the rise of a political "Malaysian Tsunami". The Diplomat. Malaysia, 10 Mei. 
Puyok, A. (2013). Malaysia's Election: Barisan Nasional's Paltry Win. East Asia Forum. Universiti Malaysia Sarawak, 29 Mei.

Rajaratnam, R. (2013). Gross Distortions In Malaysia's Voting System. Malaysia Kini News. Malaysia. 13 Mei.

Razak, T. A. (2006). Tun Abdul Razak: Potret Dalam Kenangan. Kuala Lumpur: Lembaga Pemegang Amanah Yayasan Tun Razak Utusan Publications \& Distributors Sdn Bhd.

Surin, J. A. (2015). Power and Inequality in Malaysia. Digital Development Debates. Malaysia.
Times, T. S. (2018). Malaysia's Oldest Coalition Barisan Nasional Suspended to Explore New Partnerships. The Straits Times. Kuala Lumpur, 10 Agustus.

Webmaster, M.T. (2013). Chinese Tsunami' Hits Malaysian Politics. Malaysia Today. Malaysia, 7 Mei.

Zubedy, A. (2012). The NEP - The Good And The Bad. Malaysia Today. Malaysia, 21 Juni. 